\title{
Federation: Liberalism triumphant? Or liberalism thwarted?
}

\author{
Peter Phelps
}

\section{Abstract}

The most egregious myth about Federation is that it was all about domestic issues, particularly economic issues, and that defence and foreign policy played little or no part in the impetus towards Federation. The argument runs that because little time was spent debating issues of defence and foreign affairs in the constitutional conventions, and much more time was spent on economic and fiscal matters, the latter must have been the most important drivers of Federation. The argument is unjustified in the face of the evidence. Defence and external affairs are the key to understanding the push for Federation.

\section{Introduction}

The Federation of the Australian colonies did not have the 'heroic' quality of a war of liberation, nor did it consciously adopt an ideological panegyric about 'rights', nor did it rely for its raison d'être on something like the 'European experiment' of a single customs union. As such, it has been seen by Alomes and Jones (1991) as a second-rate coming of independence-a stunted nationalism. Horne (1977, p. 154) lamented about a nation that engaged in 'a desultory debate for 20 years' and produced 'a terse and extraordinarily interesting' constitution. White (1984, p. 111) goes further: 'Federation represented less the birth of a nation ... than a readjustment of colonial relations, a somewhat shabby deal among the colonies based on deep suspicions and self-interested manoeuvring'. However, this article argues that the process of making the constitution was a remarkable exercise in assertive national liberalism, with the final document-if not its political implementation over subsequent decadesbeing a high point of Australian liberal thought. 
Part of the reason for the disparagement of the process and product of the Constitutional Conventions arises from a lack of overt explanation for Federation from the conventioneers themselves. As Ward (2001, p. 58) wrote:

The Convention debates ... offer no neat, convincing demonstrations of why the colonies federated. Indeed, the debates were more often concerned with what colonies might lose or gain by federation, or with the likely political reactions to the proposed Constitution than with the question 'Why federate?'

The responses usually fall into the popular hindsight of 'it was just inevitable'; or 'it was an expression of a new cultural nationalism' (Ward, 1966, p. 240); or the argument that capital was seeking to protect itself from the rise of socialism and trade unionism (McQueen, 1970).

It is beyond the scope of this article to go into any great detail, but the weight of evidence (Broinowski, 1992; Craven, 2001; Coulthard-Clark, 1988; Jordan, 2013; Kemp, 2019; Lehane, 2013; Meaney, 1976) is that Australian securitydefence, external affairs and immigration — was the key driver in the initial push for Federation. The leaders of the Australasian colonies themselves indicated as much in the priorities listed to encourage the move towards closer association (Intercolonial Convention, 1883 , p. 4):

It is desirable that a Federal Australasian Council should be created for the purpose of dealing with the following matters:

1. The Marine Defences of Australia, beyond territorial limits

2. Matters affecting the relations of Australasia with the Islands of the Pacific

3. The prevention of the influx of Criminals

4. The regulation of Quarantine

5. Other such matters of general Australasian interest ...

Sir Henry Parkes's 'Tenterfield Speech', so often seen as the spark for the ultimate move toward Federation, was made in response to a report that called for greater defence cooperation between the colonies_-but he took its logical implications a step further, advocating full political federation (Alomes \& Jones, 1991).

If Australian colonial leaders felt themselves compelled to move towards unification because of fears from external threats, they used the opportunity to attempt to create a new and liberal polity for the nation to come. But to examine the various responses to what the drafters thought a 'liberal' Federation would look like, we first need to address the problem of definition: what do we mean by 'liberal' and 'liberalism' in the Australian context? 
On one side you have people who historians have described, variously, as 'Classical Liberal', 'Free-Trader', 'Conservative', 'Old Liberal' and 'Liberal'. On the other side, you have people described as 'New Liberal', 'Protectionist', 'Colonial Liberal', 'Deakinite Liberal' and, confusingly, also 'Liberal'. So what is the difference?

On the first side were those who thought 'liberalism' meant a limited role for government, supported free trade and opposed protective tariffs. On the other side were those who supported greater state intervention in the economy, usually through the mechanisms of government welfare and higher tariffs on imported goods. For the purposes of this article, it is the former definition of 'liberalism' - that is 'classical liberalism', or those who favour development of individuality, support free trade and oppose the expansion of government power-that will be used as the touchstone for assessing the liberality of the Federation movement, and for the eventual constitution it produced.

Alfred Deakin himself lay down the philosophical boundaries between the two groups, even as he was obfuscating their nomenclature (in Melleuish, 2001, p. 31):

A Colonial Liberal is one who favours State interference with liberty and industry at the pleasure and in the interests of the majority, while those who stand up for the free play of individual choice and energy are classed as Conservatives.

Another of the Federation Fathers, Samuel Griffith, said (in Joyce, 1984, pp. 110, 150): 'The comfort of the individual must yield to the good of the public ... It is only the State ... that can enforce the rule of Freedom.' And Edmund Barton, Australia's first prime minister, told an audience in Maitland, New South Wales (NSW), in January 1901, just before he was about to take up office (in Gordon, 1976, p. 162):

A policy of free-trade would be impossible and would in any case be insane ... I am a protectionist as are nearly all my colleagues ... I am a protectionist and I will endeavour to protect ... the productions of our own soil.

Our industries have grown up under protection and the Government will not be a party to any policy that would be their destruction ... The first tariff will be thoroughly liberal and at the same time of a purely Australian character.

This lexicographic problem is not helped by writers like Roberts (2001) who contend that 'as an ideology and a worldview [Australian liberalism] occupies the middle ground between conservatism and socialism'. Ward likewise misidentifies George Reid as a 'New Liberal' when he was unquestionably what should be called a 'classical liberal'- his lifelong antipathy to Deakin's economic policies being an obvious point of difference. Nor is there evidence to support Ward's assertion (2001, p. 56) that 'liberalism and conservatism had been virtually indistinguishable' in colonial politics. Ward (2001) states that the 'New Liberals' or 'Deakinites' clearly believed that governments had a duty to intervene in fiscal, industrial and social 
policy in order to keep societies prosperous and secure, yet later himself falls into the Deakinite mistake of calling classical liberals 'conservatives'. Similarly, Craven (2001, p. 53) says that the Federation Fathers 'all fell within the range of what would today be referred to as liberal opinion'-but that is only true to the extent that 'liberalism' has been debased in its meaning by Deakin and his political heirs.

Nor is it simply an issue of Left vs Right. It must be remembered that, at that time, issues of religious sectarianism and economic protectionism, not capitalism vs socialism, were the major points of cleavage in Australian society. The divisions between Catholics, Anglicans and other Protestant denominations (not to mention Jews) were entrenched and bitterly contested across all spectrums of society, and would continue to be so even after Federation (Nairn, 1986). The arguments over free trade and tariffs between the colonies-what Victorian premier James Service called 'the lion in the path' to Federation-occupied the spotlight of Australian political controversy (Kemp, 2019, p. 489). That is not to say that the framers were unaware of 'class' issues, but the absence of an aristocracy-by-birth and a widespread underclass, as in Britain, meant that Australian colonial leaders were more able than Gladstone to give effect to the latter's ideal 'to create an area where rationality and the general interest could be enforced and the class will rebuked' (Vincent, 1972, p. 248). Thus, Ward is incorrect to say that federation was seen by classical liberals as a means for 'the colonies to minimise the creeping menace of socialism' (2001, p. 66). Rather, the political battles that stood in the way of Federation were largely about 'the fiscal issue' - taxes, tariffs and state intervention.

\section{The economic background to Federation}

This split between 'classical liberals' and 'Deakinites' was mirrored, geographically, by the split between political opinion in NSW and Victoria. Victoria's serendipitous but short-lived gold rush (and its inflationary consequences), combined with a lack of free land, spurred the growth of domestic manufacturing. The nineteenth-century meme of 'Father Sydney; Master Melbourne' had some validity: by 1890, Victoria had the highest rate of industrialisation, the richest trade and the greatest wealth per capita of any Australian colony (Ward, 2001).

The largest employment in secondary industry in Victoria was in clothing/textiles, breweries, sawmills, tanneries, iron foundries, brickworks, potteries and engineering establishments-but, in 1861, the average number of employees in Victorian factories was only six people (Ward, 2001). Even by the 1880s, this figure had only increased to an average of 16 workers (Kemp, 2019). There was no way that these native industries could viably compete with goods from Liverpool, or Birmingham, or Manchester-much less the United States or the growing manufacturing power of Japan. Tariff walls seemed the logical solution, after the gold boom left the 
colony's economic wellbeing dependent on the continued proliferation of small, inefficient firms. David Syme, editor of The Age, led the vanguard and he used his paper as a bully pulpit from which he attacked laissez-faire economics and competitive individualism. He leaned towards what he called 'State Socialism' and believed 'the parental authority is the basis of authority in the state'. Syme was a key influence on a young journalist and lawyer named Alfred Deakin (Melleuish, 2001; Ward, 2001). The power of Syme, arguably the first of the great activist, Australian media moguls, as an advocate for government intervention and tariffs cannot be understated.

While Victoria was moving down the path of protection and regulation, north of the Murray River it was the golden era for free trade liberalism. As Ward (2001, p. 42) notes:

Liberalism was triumphant in NSW. Everyone with a political voice to use knew that it could be used. No one with a future to make ... had cause to fear that society would withhold opportunity. Land law amendments were being made ... there was education for all who sought it. The economy was expansive. Men and women still migrated ... in hope, not despair. The belief that the colonies allowed everyone a sure prospect of full personal development to the limit of his or her abilities had become entrenched. If the system failed in particular cases, that was attributed to human folly or gross misfortune, not to lack of opportunity in a colony where, it was thought, nature's law of individual freedom had been enshrined.

Founded on agricultural and mining exports, and with a smaller domestic manufacturing industry that had had to survive without substantial tariff walls, NSW was almost monolithic in its support for free markets and free trade. NSW premier George Reid was the key political figure, following on from the freetrade principles of Sir Henry Parkes, and he instituted a series of administrative and tax reforms that saw NSW recover from the depression of the early 1890s in a better position than the other colonies (Melleuish, 2001). NSW was the centre for 'classical liberal' thought, and Reid's government, as Melleuish (2001, p. 31) notes, 'contained genuine theorists who opposed the extension of the powers of the state, and developed a coherent and modern theory of liberalism'. Bruce Smith was one of these. As early as 1887, he wrote (Smith, 2005, pp. 143, 162):

Without freedom, it is obvious that man could not choose the time, place, means or method of obtaining the requirements of life; and ... the more crowded a community becomes, the greater the necessity for freedom to the individual.

If I am right in laying down, as the fundamental principle of Liberalism, that each individual should have secured to him the most absolute liberty ... then it follows that the state should take no steps to curtail the liberty of any class, even though that other class happen to be much larger or more influential politically. 
Such language was redolent of the liberal drawing rooms of Victorian England, and indicated the deep level of cross-fertilisation of ideas between liberals in the colonies and the Mother Country. But, equally, there is a timelessness to his plea, which would also find a place in a libertarian conference of the twenty-first century. Indeed, were he able to express such views today, Smith might well be termed, by those on the Left, as a 'Neo-Liberal'.

Yet, as Melleuish (2001, p. 29) points out, a linguistic paradox developed: 'Free trade liberals found themselves saddled with the description "conservatives" while the Victorian Protectionists, who were basically statists, appropriated the term "liberal".

\section{So was Federation a triumph of classical liberalism?}

It is important to note that the Federation movements were not unitary. While there was consensus on defence, immigration and external affairs, there was a battle waged between Free Traders and Protectionists concerning the role of the state in social and economic affairs. Even the newly emergent Labor Party, in 1891, found itself divided on these matters, necessitating the introduction of a binding pledge to 'solidarity' voting, after the Party split over whether to support a Free Trader or a Protectionist for the premiership of NSW (Dyrenfurth \& Bongiorno, 2011). Ward (2001, p. 50) contends that it was merely an opportunistic coalition of interests, in the troubled 1890s, to bring about Federation, but this view appears too harsh. It is better to say that the Federation Fathers were determined to protect the security of continental Australia and, having reached that threshold decision, were determined to try make the 'shotgun marriage' of the colonies work in the more contentious areas of fiscal arrangements and the extent of centralised powers.

The very name chosen for the new nation, the Commonwealth of Australia, is significant. Canada used the term 'Federal Dominion'. Sir Henry Parkes had earlier indicated a preference that the new nation be called 'The British States of Australia' (Parkes, in The West Australian, 21 February 1884). Ward (2001) suggests that 'commonwealth' might be a nod to the United States, with the publication of a prominent political tract The American Commonwealth some three years before. These claims are unconvincing. The Federation Fathers were all steeped in the Whig history of Britain and the centrality of the English Civil War-portrayed as a gallant struggle by the people and parliament over tyranny and in defence of liberty. The new nation would be the ideal polity, a government responsible to the people and committed to the 'common weal' (Hancock, 1947, p. 95). Curran and Ward (2010, p. 265) contend that 'the use of the term reflected a sense of national idealism and the idea of a free community dedicated to the advancement of the common good'. Robert Garran, a Father of Federation and the most respected and prolific early 
interpreter of the constitution, held a deep interest in British constitutional history stretching back to the Plantagenet kings, and used 'Commonwealth' as the consistent leitmotiv in the titles of his three major publications (Milner, 2013, p. 125).

Indeed, the structure of the new nation was a litany of earlier Whig interests: a written constitution, as distinct from the Westminster system; parliamentary supremacy, with the Executive needing to obtain supply from both Houses; the separation of powers, with a clear delineation of judicial and executive power; an enumeration of all the legislative powers to be held by the government; a democratic vote, where the words 'directly chosen by the people' were embedded in the document; and a parliamentary representational structure that inevitably required the extension of that franchise, if each state wished to maintain or extend its relative power in the new federal parliament.

Federalism itself was not merely a political necessity brought about by colonial jealousies, but continued the notion of the dilution of power so as to prevent centralised tyranny. It was a recognition of the benefits of devolution and localisation of power, and it is unsurprising to note that the great Referendum failures since 1901 have been those that sought to increase central power. The drafters were not utopians. They foresaw that states could seek economic advantage for their polity, at the expense of others, and so adopted the quite remarkable provision of section 101 for the creation of an Inter-State Commission (ISC).

The ISC was created to prohibit the making of laws and regulations derogating from absolute freedom of trade between the states. It was not merely to ensure the end of internal tariffs and customs posts at borders, but also the manipulation of government-owned rail and river use through parochial government fiat. Support for this measure was so great that its remit was extended to trade and commerce generally between the states. This wide reach was largely the result of Reid, who not only worried about protectionist states, but also feared a federal government usurpation of trade transport and commerce generally. His hope was for an institution with dominant powers, but one that would be 'free from all political prejudices and unnecessary control' (Bell, 2009, p. 61).

While the enumerated legislative powers set for the federal government were, in many instances, machinery provisions, there are key liberal ideals also expressed here. In line with the ISC, there was a requirement for non-discriminatory taxes and bounties, and 'the acquisition of property on just terms'. This latter clause, s. 51(xxxi), is remarkable- 'just terms' makes it clear that outright expropriation is prohibited but, more so, that any proposed compensation would not be 'take it or leave it', but would be justiciable. None of the Australian colonies had any such constitutional requirement for their own citizens, and even the United States Constitution contained no comparable provision, despite unjust taking of property - through the quartering of British troops-being one of the grievances 
laid against King George III by the American colonists. But the Australians went further and made the apparently unnecessary reiteration that any such acquisition could only be done 'for any purpose in respect of which the Parliament has power to make laws'. This view fits absolutely within the intellectual tradition of British liberalism. Gladstone believed that only 'intellectual or moral aberration could account for such schemes as land nationalisation', and asked rhetorically of his own government (Vincent, 1972, p. 251):

Do you [the government] mean to pay for it [land], or do you not? If you mean to pay for it, it is folly: if you don't mean to pay for it, it is robbery.

Also flowing out of the English liberal tradition was the prohibition on the 'establishment' of any religion. From the 1850s onwards, the Liberation Society and other Nonconformist groups 'were extremely successful in making the [British] Liberal Party feel the weight of Nonconformist views on questions of religious equality'. They not merely motivated large numbers of people to cast votes for supportive liberals, but provided the intellectual rigour in favour of Disestablishment, which became a touchstone for their electoral support (Vincent, 1972, p. 104). In Australia, the problems of sectarianism were never far from the surface of political life, exacerbated by the fact that 80 per cent of Roman Catholics were of Irish origin, and thus the political troubles acquired a religious dimension with 'hostility, aggression, and exaggerated suspicion towards those not the same belief as themselves' (Ward, 2001, p. 19). But with no established church in the Australian colonies, their arguments were not met with the same Tory concerns about power, privilege and property - and thus the principle of non-establishment was swiftly enshrined in the Constitution. Even if the various denominations could not get on with each other, at least there would be no legal avenue for state coercion.

Moreover, in continuation of the liberal tradition, there are individual sections within the Constitution that seek to guarantee trial by jury (s. 80) on indictable offences against Commonwealth law, a prohibition on discrimination against residents of other states (s. 117), and the aforementioned free trade within the Commonwealth (s. 92), which was not merely to be 'free' but uses the seemingly redundant, but nonetheless emphatic, term 'absolutely free'.

But there were notes of illiberalism too. Four powers that were granted to the new federal government stand out in this regard. First was the inclusion of the banking and insurance powers (ss. 51(xiii) and (xiv)). In the latter case, insurance was included because of an unfounded fear from protectionists of American competition driving out domestic insurers. In the end, however, the 'free market' worked better than 'protectionism': after US insurers did enter the Australian market, they swiftly departed when they discovered that their actuarial figures were wrong, having failed to account for the fact that Australians lived longer than their US contemporaries (Ward, 2001). 
The second problem was the inclusion of a federal arbitration and conciliation power. This amendment to the draft constitution had failed twice previously, but was barely accepted in 1898 on the back of parochial concerns from the Western Australian delegation (Kemp, 2019). Third, there was the inclusion of a power over aged and invalid pensions. One supporter for this proposal, Bernhard Wise, said 'it would not be used for a Century', but was included because it was thought that it would win votes for Federation (Ward, 2001, p. 120). Finally, there were powers to handle marriage and divorce, which, like all of the above, were supposed to be deferential to existing state laws.

Craven contends that the final product was, by and large, a victory for the Free Traders, and the evidence suggests that this assessment is correct: the Australia Constitution as envisaged was a classically liberal document. But Craven (2001, p. 59) also notes: 'Paradoxically, the external federal tariff, adopted immediately after federation and which was to endure for so long, represented the application of opposite tendencies'. How did this happen? Because the first decade of Australian political life—the Federation Decade—was, for classical liberals, a disaster.

\section{The Federation Decade}

In the very first session of the Commonwealth Parliament, the Victorian Protectionist Henry Bournes Higgins persuaded the House of Representatives to pass a motion calling on the states to transfer to the federal government 'full power to make laws for Australia, as to wages and hours and conditions of work' (Commonwealth of Australia, 1901). He was an unabashed Deakinite and his motion set the tone for this formative era of Australian politics. Higgins would later be appointed to the Commonwealth Conciliation and Arbitration Court (and later the High Court), where he would write the judgment in the 1907 Harvester Case ${ }^{1}$, which would vastly expand federal government powers. As Kemp (2019, p. 377) rightly notes, the inclusion of the power of conciliation and arbitration, in s. 51, while meant by the drafters to ameliorate the effect of parochial unionism,

was to provide a doorway through which Australian unionism, and the Labor Party, walked into an unexpectedly inviting field of action, and ensured that the philosophy of systemically embedded conflict would soon come to exercise and influence on the new nation's affairs.

Things were no better on the issue of protective tariffs. Barton was also determined to back protectionism at the expense of free trade. The Customs Tariff Act 1902 set the initial rates, and Lloyd (2015) has estimated that it increased the average rate of customs duty on dutiable imports from outside the Commonwealth by

1 Ex Parte H.V. McKay (1907) 2 CAR 1. 
about 34 per cent. Despite this, Protectionists remained dissatisfied and, in 1905, when Deakin formed government, he gave notice of his desire to raise the levels of protection even further. Combining with a Labor Party that now also supported higher tariffs, ostensibly to protect Australian workers' jobs and conditions of employment, they passed the Customs Tariff Act 1908, which cemented Australia into high levels of protection for manufactured goods. It represented the triumph, in both parliament and Australian public discourse, of protectionism over free trade. The average rate of duty on dutiable imports increased from 26.2 per cent in 1907 to 30.6 per cent in 1908 . By the early 1930s, the average rate was over 70 per cent, and Australia would not see a return to pre-Federation tariff levels until the late 1990s (Lloyd, 2008).

By 1909 there was a federal aged pension. By 1910 there was also a federal invalid pension, in direct refutation of Wise's stated belief that those powers would not be used for a hundred years. And by the early 1960s, the state marriage and divorce laws were all subsumed by Federal Liberal Attorney-General Garfield Barwick's Matrimonial Causes Act 1959 and Marriage Act 1961 (Barwick, 1995).

How could this have happened? In the first decade after Federation, Deakin was prime minister for almost 60 per cent of the time, and this was despite support for the Protectionists continuing to fall at each election. The numbers are striking: at the 1901 Federal Election, Protectionists held 31 seats, Free Traders 28 seats and Labor 14 seats. At the 1903 election, the numbers were 26, 23 and 25 respectively. And by 1906 the Protectionists only held 16 seats, compared with 27 for the Free Traders and 26 for Labor (Marsh, 2001).

Until the 'Fusion' of the Protectionist and Free Trade parties in 1909, Deakin and the other Protectionists were continually dependent on Labor support. In chronological order, the Australian governments in that first decade of nationhood were:

- Protectionist backed by Labor

- Protectionist backed by Labor

- Protectionist backed by Labor

- Labor backed by Protectionist

- Free-Trade (Reid) backed by Protectionist (for only 10 months)

- Protectionist backed by Labor

- Protectionist backed by Labor

- Labor backed by Protectionist.

Exploratory discussions on more durable linkages between Labor and Protectionists were held in 1904, and again as late as 1908-just a year before the Fusion between the Free Traders and the Protectionists (Marsh, 2001). In other words, Deakin clearly saw greater possibilities for a permanent relationship between Labor and 
Protectionists, and expended more energy attempting to get a lasting partnership with them, rather than with the party with which he would ultimately make the Fusion deal.

As Gorman (2018) notes, Deakin was not a socialist, but he was naïve about its potential dangers, believing that, at worst, 'socialism' could only be carried out at the level of state government, given the (supposed) limited responsibilities of the federal government. Nevertheless, Deakin still wanted the power of the state to be used to guarantee minimum wage rates; old-age pensions; free compulsory state education; the redistribution of wealth by taxation; and 'some legislation to cut the impact upon men and women of capitalist enterprise concerned with profit' and, thus, Deakin 'continued to regard Labor and [Protectionists] as natural allies' (Ward, 2001, p. 74).

Contrast this policy position with George Reid, the Free Trade leader, who like Joseph Carruthers saw that socialism, not protectionism, was the political enemy of the future (Gorman, 2018). Reid lays the issue out squarely in his 1906 election speech, while at the same time taking a firm swipe at Deakin:

The Labor-Socialist leagues are doing one good thing for Australian politics - they are striving to get rid of the system of three parties just as strenuously as we are ... They believe their party has a future. We know the [Deakin] Government has only a past. Unless you, ladies and gentlemen, respond either to the appeal of the [Free Trade] Opposition or the appeal of the Socialists, you will be the real authors of another miserable period of intrigue.

What is the appeal the shattered Deakin Administration makes for a continuance of its humiliating career? What great, inspiring cry comes from Ballarat? Nothing but a wail over a distress which does not exist, in order to fill the pockets of a few men who already have enough out of the taxpayers. (Sydney Morning Herald, 24 October 1906)

By the time Deakin understood the threat from socialism, and sought Fusion with the Free Traders, it was too late-the 'Australian Settlement', as Kelly (1992) described it, was locked into place. The 'Settlement' consisted of the 'White Australia' policy, protective tariffs on imported manufactures, compulsory conciliation and arbitration of industrial disputes, and federal government expansion into social welfare. With Fusion, Deakin not only required the excision of Reid's influence, he cemented the ideological baggage of protectionism within the new party. When the British Economic Mission came to Australia in 1929, it 'reported in both sorrow and anger the protectionist propensities of the Australians, waring that no lasting progress could occur under such conditions' (Millar, 1980, p. 92). Yet Deakin remains an avatar of popular 'Australian Liberalism', while people like Reid, Smith and Carruthers all fell out of the pantheon of liberal heroes as 'the policy of free trade and minimal interventionism ... suffered a bad press' (Staley \& Nethercote, 2001). As Melleuish (2001, p. 35) wrote: 
Reid's advocacy of 'anti-socialism' was the foundation for Fusion, and yet the Liberal Party thereby created was defined intellectually largely by Deakin's statism. For the next 60 years, classical liberalism what not really central to Australian Liberalism; Australian Liberalism in these years was mainly a combination of Deakinite statism, populism, and conservatism.

\section{Conclusion}

So did Australian Federation represent liberalism triumphant or thwarted? The Constitution is a profoundly liberal document-both in its democratic construction and, with some exceptions, in its final form. But there is also no doubt that, even in the lifetime of the participants of the Constitutional Conventions, their expectations of what the federal government should look like, and what it actually did look like, were wildly different. Certainly, the polity envisaged by the framers did not live up to the reality of the politics, as the federal government expanded its power at almost the first available opportunity, and has continued to do so ever since. A mixture of judicial and political activism, the collapse of the ISC (at the hands of a centralist High Court of Australia), and the precarious nature of federal-state fiscal relations all had strongly illiberal tendencies for the new federation. Carruthers spent a great deal of time and effort in his declining years, inside and outside the NSW Legislative Council, fighting against that expansion of federal government power (Gorman, 2018). If blame is to be laid —and that is a big 'if' without falling into the arrogance of hindsight - it must be laid with those who believed that classical liberalism would remain unchallenged in perpetuity.

In that regard, it is instructive to note the absence in the Australian Constitution of a comparable clause to that found in the Tenth Amendment of the US Constitution:

The powers not delegated to the United States by the Constitution, nor prohibited to it by the States, are reserved to the States respectively, or to the people.

It is arguable that a clause of this nature in the Australian Constitution would have, even if not ending the centralist and expansive tendencies of the federal government, at least substantially slowed them down. But Australia's Federation Fathers were far more complacent than their American brethren, and they misread the temptations of federal power-and none more so than Deakin himself. They believed that there was no need to set formal constitutional constraints on the power of the federal government, as the Americans had chosen to do, because everyone within their circle, to a greater or lesser degree, accepted the liberal norms about the limits of federal government power. In their world view, the states would do what the states did in 1895, and the federal government would limit itself to only those things which the states could not do. It was not to be so-but that does not detract from the classical liberal motivations of those involved, nor the classical liberal spirit within which Australia's foundational document was created. 


\section{References}

Alomes, S. \& Jones, C. (1991). Australian nationalism: A documentary history. Angus \& Robertson.

Barwick, G. (1995). A radical Tory: Garfield Barwick's reflections and recollections. Federation Press.

Bell, A. (2009). The missing constitutional cog: The omission of the Inter-State Commission. Bar News, Summer (2009-2010), 59-74.

Broinowski, A. (1992). The yellow lady: Australian impressions of Asia. Oxford University Press.

Commonwealth of Australia. (1901). Parliamentary debates, House of Representatives, 28 June 1901. parlinfo.aph.gov.au/parlInfo/genpdf/hansard80/hansardr80/1901-06-28/ 0027/hansard_frag.pdf;fileType=application/pdf.

Coulthard-Clarke, C.D. (1988). Formation of the Australian armed services, 1901-1914. In M. McKernan \& M. Browne (Eds), Australia: Two centuries of war \& peace (pp. 121143). Australian War Memorial.

Craven, G. (2001). A liberal Federation and a liberal constitution. In J.R. Nethercote (Ed.), Liberalism and the Australian Federation (pp. 53-68) Federation Press.

Curran, J. \& Ward, S. (2010). The unknown nation: Australia after Empire. Melbourne University Press.

Dyrenfurth, N. \& Bongiorno, F. (2011). A little history of the Australian Labor Party. UNSW Press.

Gordon, H. (1976). An eyewitness history of Australia. Rigby.

Gorman, Z. (2018). Sir Joseph Carruthers: Founder of the News South Wales Liberal Party. Connor Court.

Hancock, W.K. (1947). Politics in Pitcairn: And other essays. Macmillan.

Horne, D. (1977). The lucky country. Dominion Press.

Intercolonial Convention. (1883). Report of the proceedings of the Intercolonial Convention, held in Sydney, in November and December, 1883. George Dempsey.

Jordan, M. (2013). The Chinese immigration crisis of 1888 and the coming of White Australia. In J. Beaumont \& M. Jordan (Eds), Australia and the world: A festschrift for Neville Meaney (pp. 57-80) Sydney University Press.

Joyce, R.B. (1984). Samuel Walker Griffith. University of Queensland Press.

Kelly, P. (1992). The end of certainty: The story of the 1980s. Allen \& Unwin.

Kemp, D. (2019). A free country: Australians'search for Utopia 1861-1901. Miegunyah Press. 
Lehane, R. (2013). A military mission for Greater Britain: Edward Hutton's 'A co-operative system for the defence of the Empire'. In J. Beaumont \& M. Jordan (Eds), Australia and the world: A festschrift for Neville Meaney (pp. 101-119). Sydney University Press.

Lloyd, P. (2008). 100 years of tariff protection in Australia. Australian Economic History Review, 48(2), 99-145. doi.org/10.1111/j.1467-8446.2008.00233.x.

Lloyd, P. (2015). Customs union and fiscal union in Australia at Federation. Economic Record, 91(293), 155-171. doi.org/10.1111/1475-4932.12167.

Marsh, I. (2001). The Federation Decade. In J.R. Nethercote (Ed.), Liberalism and the Australian Federation (pp. 69-97). Federation Press.

McQueen, H. (1970). A new Britannia. Penguin.

Meaney, N. (1976). The search for security in the Pacific 1901-1914. Sydney University Press.

Melleuish, G. (2001). Australian liberalism. In J.R. Nethercote (Ed.), Liberalism and the Australian Federation (pp. 28-41). Federation Press.

Millar, J.B.D. (1980). 'An Empire that don't care what you do ...' In A.F. Madden \& W.H. Morris-Jones (Eds), Australia and Britain: Studies in a changing relationship (pp. 90-100). Sydney University Press.

Milner, C. (2013). Robert Randolph Garran and the creation of the Australian Commonwealth. In J. Beaumont \& M. Jordan (Eds), Australia and the world: A festschrift for Neville Meaney (pp. 121-144). Sydney University Press.

Nairn, B. (1986). The 'Big Fella': Jack Lang and the Australian Labor Party 1891-1949. Melbourne University Press.

Roberts, W. (2001). Liberalism: The nineteenth century legacy. In J.R. Nethercote (Ed.), Liberalism and the Australian Federation (pp. 42-50). Federation Press.

Smith, B. (2005). Liberty and liberalism. Centre for Independent Studies. (Original work published 1887).

Staley, T. \& Nethercote, J. (2001). Liberalism and the Australian Federation. In J.R. Nethercote (Ed.), Liberalism and the Australian Federation (pp. 1-10). Federation Press.

Vincent, J. (1972). The formation of the British Liberal Party, 1857-68. Penguin.

Ward, J.M. (2001). The state \& the people: Australian Federation and nation-making 18701901. Federation Press.

Ward, R. (1966). The Australian legend. Oxford University Press.

White, R. (1984). Inventing Australia: Images and identity 1688-1980. Allen \& Unwin. 
This text is taken from Agenda, Volume 27 - Number 1, 2020, edited by William Coleman, published 2020 by ANU Press, The Australian National University, Canberra, Australia.

doi.org/10.22459/AG.27.01.2020.08 